\title{
CHARACTERIZATION OF MACROFAUNA ASSOCIATED WITH ARTICULATED CALCAREOUS ALGAE (CORALLINACEAE, RHODOPHYTA) OCCURRING IN A HYDRODYNAMIC GRADIENT ON THE ESPÍRITO SANTO STATE COAST, BRAZIL
}

\author{
Rômulo José Ramos ${ }^{1,2 *}$, Marcelo Poças Travassos ${ }^{3}$ and Gustavo Rocha Leite ${ }^{1,2,4}$ \\ ${ }^{1}$ Instituto da Biodiversidade, IBIO \\ (Rua Dr. João Batista Miranda Amaral, 285, 29090-380 Vitória, ES, Brasil)
}

${ }^{2}$ Programa de Pós-Graduação em Biologia Animal da Universidade Federal do Espírito Santo (Av. Marechal Campos 1468, 29043-900 Vitória, ES, Brasil)

${ }^{3}$ Associação Brasileira de Oceanografia - AOCEANO

(Rua 1500, 710, 88330-524 Balneário Camboriú, SC, Brasil)

${ }^{4}$ Unidade de Medicina Tropical da Universidade Federal do Espírito Santo

(Av. Marechal Campos 1468, 29043-900 Vitória, ES, Brasil)

*Corresponding author: ramosjromulo@yahoo.com.br

\begin{abstract}
A B S T R A C T
The aims of this study were to characterize the macrofauna associated with the articulated calcareous algae occurring on a hydrodynamic gradient off the Vitória metropolitan area, Espírito Santo State, Brazil, and to describe its temporal distribution. Physicochemical variables were measured in situ, and samples of sediment, water and phytal were taken from three sites along the coast in August and November 2005 (winter and spring, respectively) and in February and May 2006 (summer and fall, respectively). Twenty random samples were taken from the rocky surface in the lower midlittoral zone at each site, each season. Six species of articulated algae harboring 9,651 animal specimens distributed among 189 taxa were collected. The dominant taxonomic groups were Mollusca, Polychaeta and Crustacea. The main patterns revealed by statistical analysis related to differences in the abundance and richness at the sample sites, as well as to the correlation between the physicochemical variables and community distance matrices, indicating the importance of the physicochemical variables in the differentiation of the communities. Results also indicated that the variable which most influenced the physicochemical and community properties was the hydrodynamic character of the sites: a high level of hydrodynamism resulting in the calcareous algae's sheltering a lower abundance and diversity of animal species than a lower level one
\end{abstract}

\section{R ESUMO}

Os objetivos deste estudo foram caracterizar a macrofauna associada às algas calcárias articuladas num gradiente de hidrodinamismo no litoral da região metropolitana de Vitória, Espírito Santo, Brasil, e descrever a distribuição temporal. Variáveis fisicoquímicas foram medidas in situ, e amostras do sedimento, água e fital foram feitas em três pontos amostrais do litoral em agosto e novembro de 2005 (inverno e primavera, respectivamente) e fevereiro e maio de 2006 (verão e outono, respectivamente). Em cada ponto, e por estação do ano, foram obtidas 20 amostras aleatórias da superfície do costão rochoso na região do mediolitoral inferior. Seis espécies de algas calcárias articuladas foram coletadas e abrigaram 9.651 espécimes animais distribuídos em 189 táxons. Os grupos taxonômicos dominantes foram Mollusca, Polychaeta e Crustacea. Os principais padrões revelados pelas análises estatísticas foram diferenças na abundância e riqueza entre os pontos amostrais e correlação entre as variáveis fisicoquímicas e a comunidade, indicando que os parâmetros fisicoquímicos foram importantes para a caracterização destas. Os resultados indicaram ainda que a variável que mais influenciou as propriedades fisicoquímicas e da comunidade foi o grau de hidrodinamismo: locais com hidrodinamismo elevado permitem que algas calcárias abriguem uma menor abundância e diversidade de espécies animais do que locais com hidrodinamismo elevado.

Descriptors: Rocky shore, Phytal, Calcareous algae, Associated fauna, Hydrodynamism, Organic matter.

Descritores: Costão rochoso, Fital, Alga calcária, Fauna associada, Hidrodinamismo, Matéria orgânica. 


\section{INTRODUCTION}

Coastal benthic habitats belong to the most productive marine ecosystems. In intertidal areas, hard substrates are known to be important as they provide shelter for many species that are of ecological and economic value. These areas present abundant macroalgal biomass because of the great amount of nutrients received from the terrestrial system (KELAHER; CASTILHA, 2005).

Macroalgae, including the calcareous algae, have a structural complexity that favors the settling of many organisms and, moreover, they serve as a substrate for vagile organisms, providing food, refuge against predators and protection from waves (BARRETO, 1999; HULL, 1999). Thus, these algae form an essential link in the coastal food chain, sheltering many organisms that depend on phytal at some stage of their life cycle (FERREIRA; MAIDA, 2001).

Calcareous algae accumulate sediment among their thallii, providing new microenvironments that influence the composition of phytal and thus favoring the association with other algal and animal communities (MASUNARI, 1982; 1983). In the case of sudden changes, whether climatic or of seasonal characteristics. the macrofauna associated with these algae, of which Crustacea and Mollusca are the main representatives also undergoes changes in its composition (LEITE et al., 2007). Besides the hydrodynamic characteristics, this ecosystem is also influenced by biotic and abiotic variables, the oscillations in water temperature, salinity, and water quality being particularly relevant (TÂMEGA; FIGUEIREDO, 2005). Furthermore, significant changes have occurred in those coastal communities in the proximity of urban centers because of the rapid degradation caused by man, especially in those having an important role in the food chain (TEIXEIRA et al., 1987; UNDERWOOD; PETERSON, 1988; OIGMAN-PSZCZOL et al., 2004).

Although many studies have described the macrofauna associated with algae in Brazil (e.g., MASUNARI, 1983 ; DUBIASKI-SILVA; MASUNARI, 1995), studies describing the fauna associated with articulated Corallinaceae are rare, especially as regards the State of Espírito Santo. There are only a few studies that have sought to ascertain the relevance of physicochemical and biological factors in the composition of these communities because of the complexity of ecological interactions in the phytal communities (e.g., POCKLINGTON; WELLS, 1992; MENGE, 2000; OIGMAN-PSZCZOL et al., 2004; KELAHER; CASTILHA, 2005). As a result, there is a lack of the information necessary for structural and functional analyses of the phytal communities in Brazil. The aims of this present study are to characterize the macrofauna associated with the articulated calcareous algae living on a hydrodynamic gradient on the coast of the State of Espírito Santo and to describe its temporal distribution.

\section{Material and Methods}

\section{Study Area}

The metropolitan region of Vitória, State of Espírito Santo, Brazil, is situated in an area where a crystalline formation outcrops at the coast resulting in an irregular coastline with sites either exposed to or protected from the direct action of the waves (SUGUIO et al., 1985). This region has undergone considerable anthropological interference in recent decades, including the construction of harbors and a steel complex, and, consequently, it receives a considerable discharge of domestic and industrial effluents. This interference has caused changes both in the lie of the coastline and in the physicochemical conditions of both water and sediment (NASSAR; VALENTIN, 2006; STERZA; FERNANDES, 2006).

Three collection sites with different hydrodynamic characteristics were established within the metropolitan region of Vitória, two of them located in the municipality of Vitória itself and the other in the municipality of Serra: the Ilha do Frade, an island under legal protection for recreational purposes; Camburi, an area also widely used for recreation, with some changes in its original beach profile due to a variety of constructions; and Carapebus, a legally protected area but not used for recreation (Fig. 1).

According to SZÉCHY and PAULA (2000), protected places are those within bays where geographical or man-made accidents create a barrier to winds or strong currents. On the other hand, exposed places are those outside bays, on which the waves beat. In an intermediary situation, there is moderate hydrodynamism. Based on these authors, it may be inferred that the first two sites of the present study (Ilha do Frade and Camburi) have lower level hydrodynamism than the third site (Carapebus).

\section{Sampling Procedures}

The samples for this study were collected in August and November 2005 (winter and spring, respectively) and in February and May 2006 (summer and fall, respectively), during low tide along transects parallel to the coastline in the lower midlittoral zone. At each sampling site, a rocky area of about $60 \mathrm{~m}^{2}$ (intertidal zone $\times$ coastline) was selected, within which 20 sampling quadrats $(10 \times 10 \mathrm{~cm})$ were launched at random, in accordance with SABINO and VILLAÇA (1999). Ten of these quadrats were sampled in the first 
fortnight of each sampling month and the remaining 10 in the second fortnight. This procedure was adopted in order to reduce the effect of any sudden changes in the weather (e.g., excessive rainfall).

The temperature, dissolved oxygen, salinity and $\mathrm{pH}$ of sea water were measured in situ. The organic particulate matter in the water was determined by filtering $200 \mathrm{ml}$ of sea water through a glass-fiber filter, and the filtrate was weighed before and after burning in a muffle furnace at $450^{\circ} \mathrm{C}$ for $2 \mathrm{~h}$. The organic matter in the sediment was determined by burning $5 \mathrm{~g}$ of sediment with sulfuric acid to remove bioclast, dried at $105^{\circ} \mathrm{C}$, and the processed sediment was weighed before and after burning in the muffle furnace at $550^{\circ} \mathrm{C}$ for $4 \mathrm{~h}$. The percentage of organic matter was calculated from the difference between the weights of the processed sediment before and after combustion (see WETZEL; LIKENS, 1991).

The sediment on the hard substrate was collected manually and analyzed to characterize its granulometric percentage composition, determined by drying $50 \mathrm{~g}$ of sediment at $70{ }^{\circ} \mathrm{C}$ and passing it through granulometric sieves. Based on their size, the particles were classified into gravel $(>2 \mathrm{~mm}$ diameter), sand $(0.5-2 \mathrm{~mm})$, medium sand $(0.25-$
$0.5 \mathrm{~mm})$, fine sand $(0.06-0.25 \mathrm{~mm})$ and silt-clay $(<$ $0.06 \mathrm{~mm})$.

The rocky surface's degree of exposure to waves (hydrodynamism) was defined in terms of the surface's position in relation to the coastline and of the presence of geographical (e.g., islands) or man-made accidents (e.g., piers and harbors). However, in order to confirm this classification of the hydrodynamism of the sites under study, plaster structures weighing $75 \mathrm{~g}$, connected to PVC tubes and attached to a $15 \mathrm{~kg}$ cement block, were used. Three of these structures were submerged at each sample site concomitantly for $24 \mathrm{~h}$. The hydrodynamic level at each site was determined from the difference between the initial and final weights of the plaster structures (see GUERRAGARCÍA; GARCÍA-GOMEZ, 2001).

Samples of phytal were taken from the rocky surface. The whole area of calcareous algae within the quadrat was scraped with a metallic spatula and the samples were placed in individual containers. The phytal samples were washed in the laboratory, and the associated macrofauna that was retained on a $0.5 \mathrm{~mm}$ sieve mesh was sorted, identified and preserved in $70 \%$ alcohol. The biovolume of the algae was also quantified.

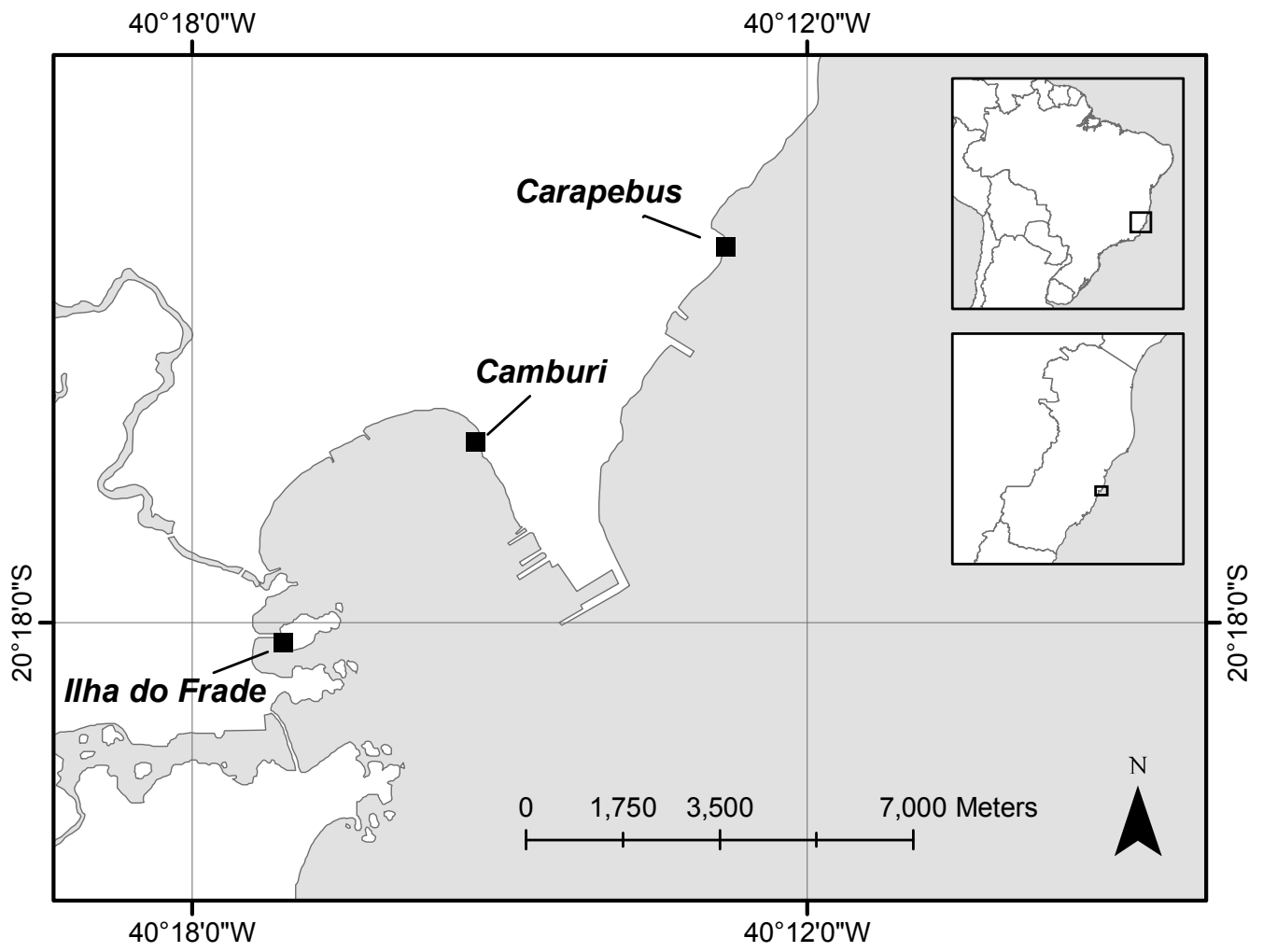

Fig. 1. Map of metropolitan region of Vitória, Espírito Santo, Brazil, indicating the location of the three sampling sites (quadrats). 
Data Analysis

For each quadrat, the abundance, taxa richness, Shannon-Wiener's diversity and Pielou's evenness indices were calculated. The bifactorial analysis of variance (two-way ANOVA) together withTukey's HSD test was used to evaluate the differences in these ecological indices of the different communities, between sampling sites and seasons. Normality of data and variance homogeneity were verified using the Kolmogorov-Smirnov test and Levene's test, respectively. When necessary, data were transformed by the Box-Cox method to avoid the violation of assumptions of normality and homoscedasticity (see ZAR, 1999).

The dissimilarity between sampling sites and seasons was calculated using Euclidean distance for algal biovolume, water temperature, dissolved oxygen, salinity, $\mathrm{pH}$, organic matter in water and sediment, and sediment granulometry. Cluster analysis was based on the unweighted pair-group method using arithmetic averages (UPGMA) algorithm. The communities at each sampling site and in each season were grouped by cluster analysis based on UPGMA and the Morisita-Horn dissimilarity index. The Mantel test was used to check the correlation between the two distance matrices (parameters and communities), and Monte Carlo simulation with 1000 random permutations was used to assess the significance of the Mantel test (see KREBS, 1989). Data transformation, statistical analysis, and ecological indices were calculated using the statistical package $\mathrm{R}$ version 2.4.0 (http://www.R-project.org).

\section{RESULTS}

Abiotic Variables

Monthly average rainfall in the year of sampling was $270 \mathrm{~mm}$. The least and most rainy seasons were the winter (193 mm/month) and the summer (385 $\mathrm{mm} / \mathrm{month}), \quad$ respectively (Meteorological Station of Vitória Airport, Vitória, Espírito Santo, Brazil).

Water temperature oscillated from 22 to $29^{\circ} \mathrm{C}$, dissolved oxygen from 5.0 to $10.6 \mathrm{mg} . \mathrm{L}^{-1}$, salinity from 32 to $37, \mathrm{pH}$ from 7.7 to 8.9 , organic matter in the water from 1.4 to $13.0 \mathrm{mg} . \mathrm{L}^{-1}$, organic matter in the sediment from 0.1 to $1.5 \mathrm{mg} . \mathrm{L}^{-1}$ and algal biovolume from 0.1 to $0.5 \mathrm{~L}$ (Fig. 2), considering all the sampling sites and seasons. The granulometric composition of sediment resulted in sand for Ilha do Frade, silt-clay for Camburi and gravel for Carapebus. The experiment to estimate the hydrodynamic level of the sampling sites confirmed the characterization established by SZÉCHY and PAULA (2000). Ilha do Frade presented the lowest difference between initial and final weights of the plaster structure (40.2\%), Camburi presented an intermediate difference between weights (62.2\%) and Carapebus the highest difference (76.3\%) (Table 1).

\section{Macroalgae}

A total of six species of articulated calcareous algae were recorded from phytal samples: Amphiroa beauvoisii J.V. Lamouroux, Amphiroa fragilissima (Linnaeus) J.V. Lamouroux, Arthrocardia flabellate (Linnaeus) J.V. Lamouroux, Corallina panizzoi Schnetter and U. Richter, Jania adhaerens J.V. Lamouroux and Jania crassa J.V. Lamouroux (see WYNNE, 2005). On Ilha do Frade and Camburi, the most abundant species was A. beauvoisii followed by A. fragilissima and $A$. flabellate, forming a low carpet of entangled thallii in a well-defined coastal belt. At Carapebus, the most abundant species was $C$. panizzoi followed by $J$. adhaerens and J. crassa, forming a tall carpet of voluminous erect thallus.

\section{Macrofauna}

A total of 9,651 animal specimens distributed among189 taxa were collected from the three sampling sites. The dominant taxonomic groups were Mollusca (3,299 specimens, 60 taxa), followed by Polychaeta $(1,226$ specimens, 57 taxa $)$ and Crustacea (4,575 specimens, 63 taxa). Porifera, Hydrozoa, Nemertinea, Nematoda, Sipuncula, Pycnogonida and Echinodermata (551 specimens, 9 taxa) were also present in the samples. As regards the Mollusca, Bostrycapulus aculeatus (Gmelin, 1791), Eulithidium affine (Adams, 1850), Fissurella rosea (Gmelin, 1971) and Crassostrea rhizophorae (Guilding, 1828) were the most abundant species. As for Polychaeta, Typosyllis sp., Nothria sp., Cabira sp. and Langerhansia sp. were the most abundant taxa. Among the Crustacea, Hyale media (Dana, 1853), Elasmopus brasiliensis (Dana, 1853), Hyale nigra (Haswell, 1879,) and Aruga holmesi Barnard, 1955 were the most abundant species. Of other less representative groups, the Echinodermata Amphipholis squamata (Chiaje, 1828) was the most abundant.

Ilha do Frade presented the highest abundance and species richness (4,792 specimens, 150 taxa), where Mollusca dominated (2,335 specimens, 44 taxa). On the other hand, at Camburi, the second most abundant site (3,304 specimens, 132 taxa), Crustacea dominated (2,034 specimens, 51 taxa). At Carapebas, where the lowest abundance and species richness were recorded (1,555 specimens, 95 taxa), Crustacea dominated (927 specimens, 35 taxa). The Ilha do Frade presented the highest exclusive Polychaeta (17 taxa) and Mollusca richness (10 taxa). Camburi also presented 10 exclusive Mollusca taxa and the highest richness for exclusive Crustacea (9 taxa) as well. Carapebus presented only four exclusive taxa between Crustacea and Mollusca. 

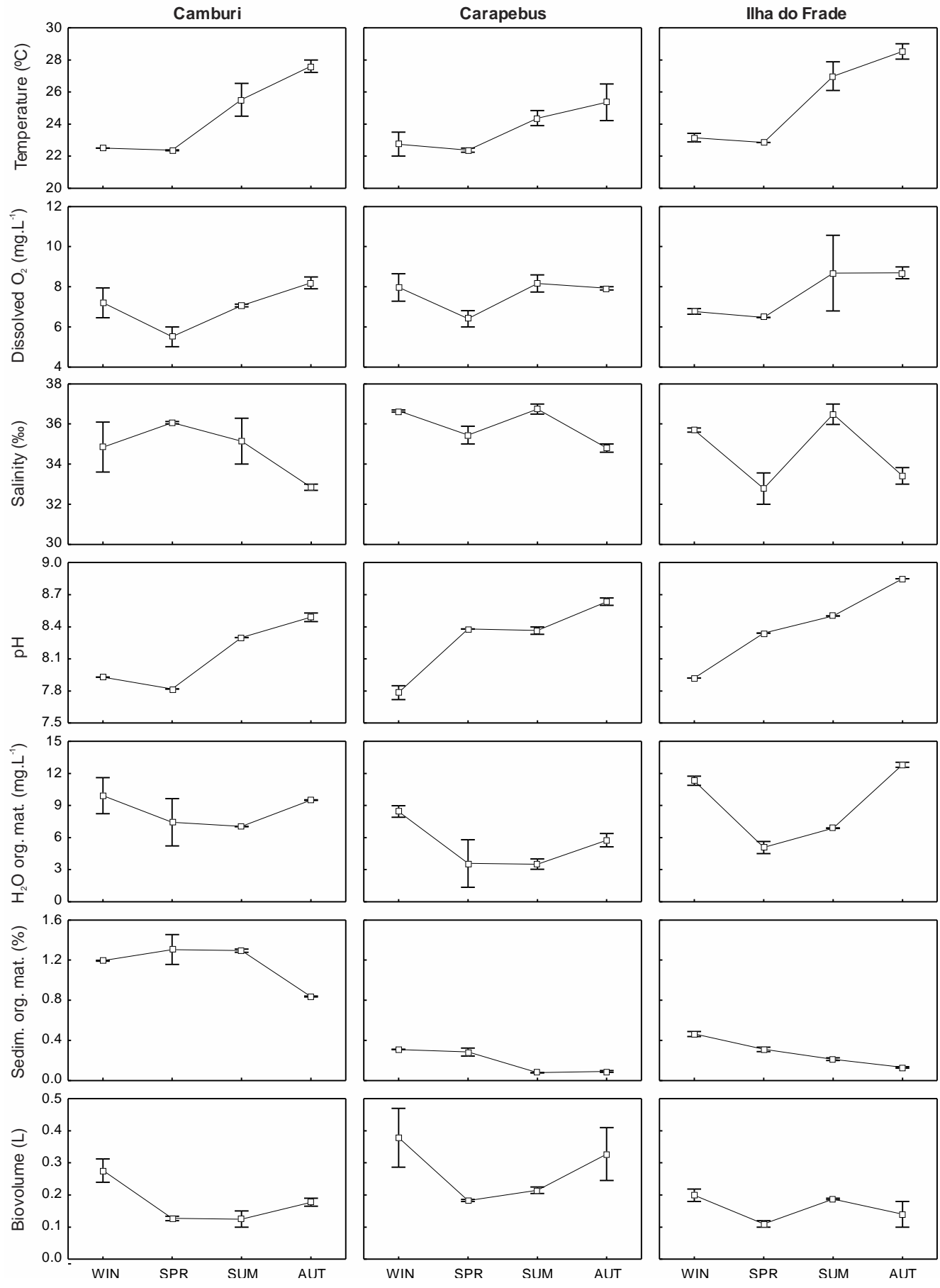

Fig. 2. Mean $\pm 95 \%$ confidence interval of physicochemical and biological variables at each sampling site by season. WIN, Winter; SPR, Spring; SUM, Summer; AUT, Autumn. 
Table 1. Characteristics of sampling sites studied in the metropolitan region of Vitória, Espírito Santo, Brazil.

\begin{tabular}{|c|c|c|c|}
\hline \multirow[b]{2}{*}{ Characteristic } & \multicolumn{3}{|c|}{ Sampling sites } \\
\hline & $\begin{array}{l}\text { Ilha do } \\
\text { Frade }\end{array}$ & Camburi & Carapebus \\
\hline Hydrodynamism & Low & Medium & High \\
\hline $\begin{array}{l}\text { Range of intertidal } \\
\text { zone }\end{array}$ & $4 \mathrm{~m}$ & $6 \mathrm{~m}$ & $7 \mathrm{~m}$ \\
\hline Domestic sewage* & High & High & Low \\
\hline Type of substrate & Granitic & Lateritic & Lateritic \\
\hline $\begin{array}{l}\text { Particle size of } \\
\text { sediment on the rocky } \\
\text { beach surface }\end{array}$ & Sand & Silt-clay & Gravel \\
\hline
\end{tabular}

* The amount of domestic sewage received by each sampling site was characterized according to its proximity to urban centers and to the discharge of rivers that pass through these urban centers

In the winter, the highest richness was recorded for total species (140 taxa), Mollusca (39 taxa), Crustacea (56 taxa) and other groups (6 taxa), while in the fall the highest abundance of Polychaeta (450 specimens) and total abundance $(3,133$ specimens) was obtained.

\section{Community Parameters}

Abundance oscillated from 0 to 151 , richness from 0 to 29 , diversity from 0 to 2.87 and evenness from 0 to 1, for each quadrat (Figs 3 and 4). The main patterns shown by two-way ANOVA and Tukey's HSD test were the statistical differences in abundance and richness between the three sample sites (Table 2). Cluster analysis of physicochemical and algal biovolume rendered the formation of two groups: Camburi and Ilha do Frade/Carapebus. Community cluster evidenced three groups, Ilha do Frade, Camburi, and Carapebus (Fig. 5). The Mantel test showed a significant positive correlation between the two distance matrices $(r=0.34 ; p<0.01)$.
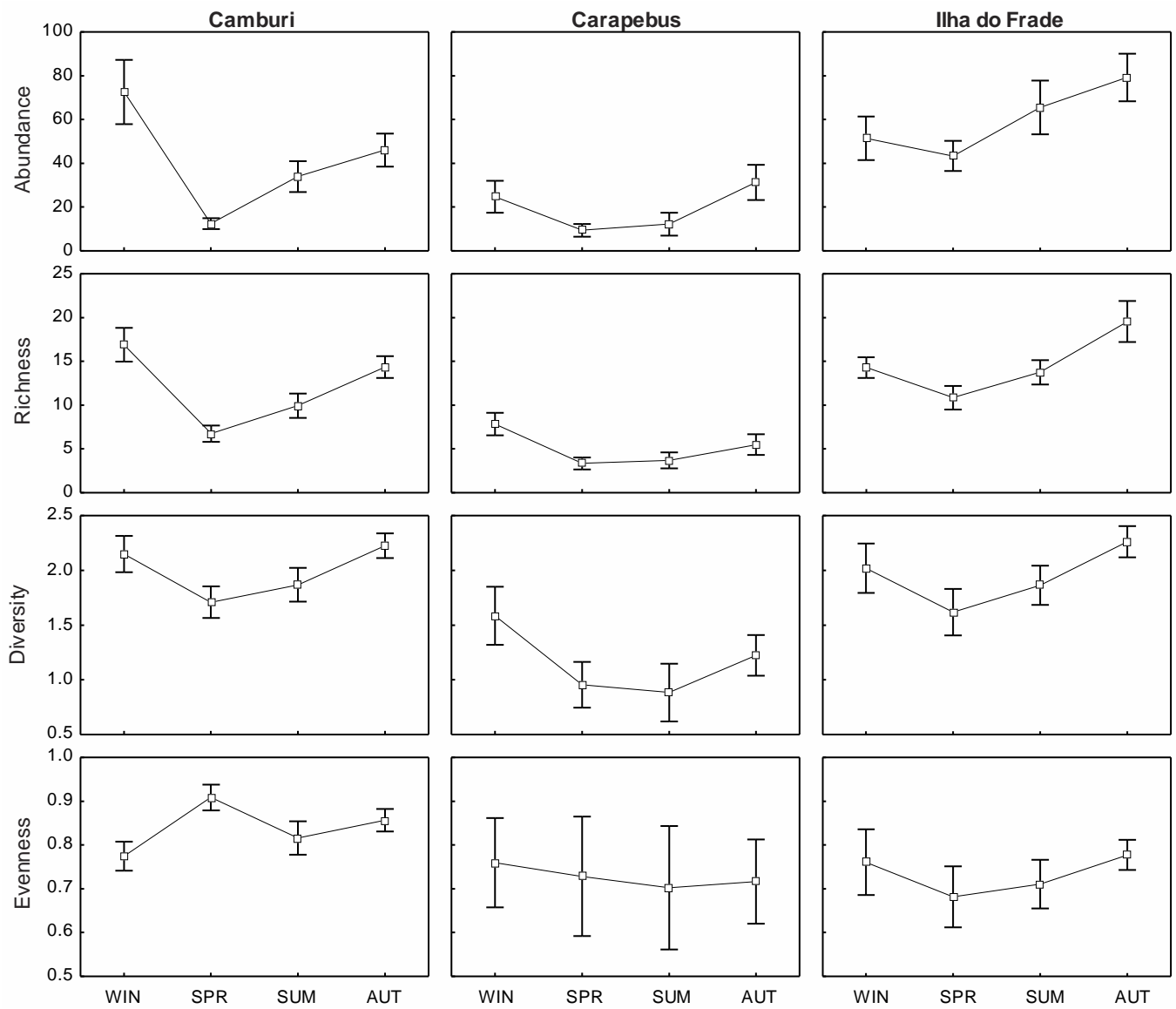

Fig. 3. Mean $\pm 95 \%$ confidence interval of the ecological indices at each sampling site by season. WIN, Winter; SPR, Spring; SUM, Summer; AUT, Autumn. 

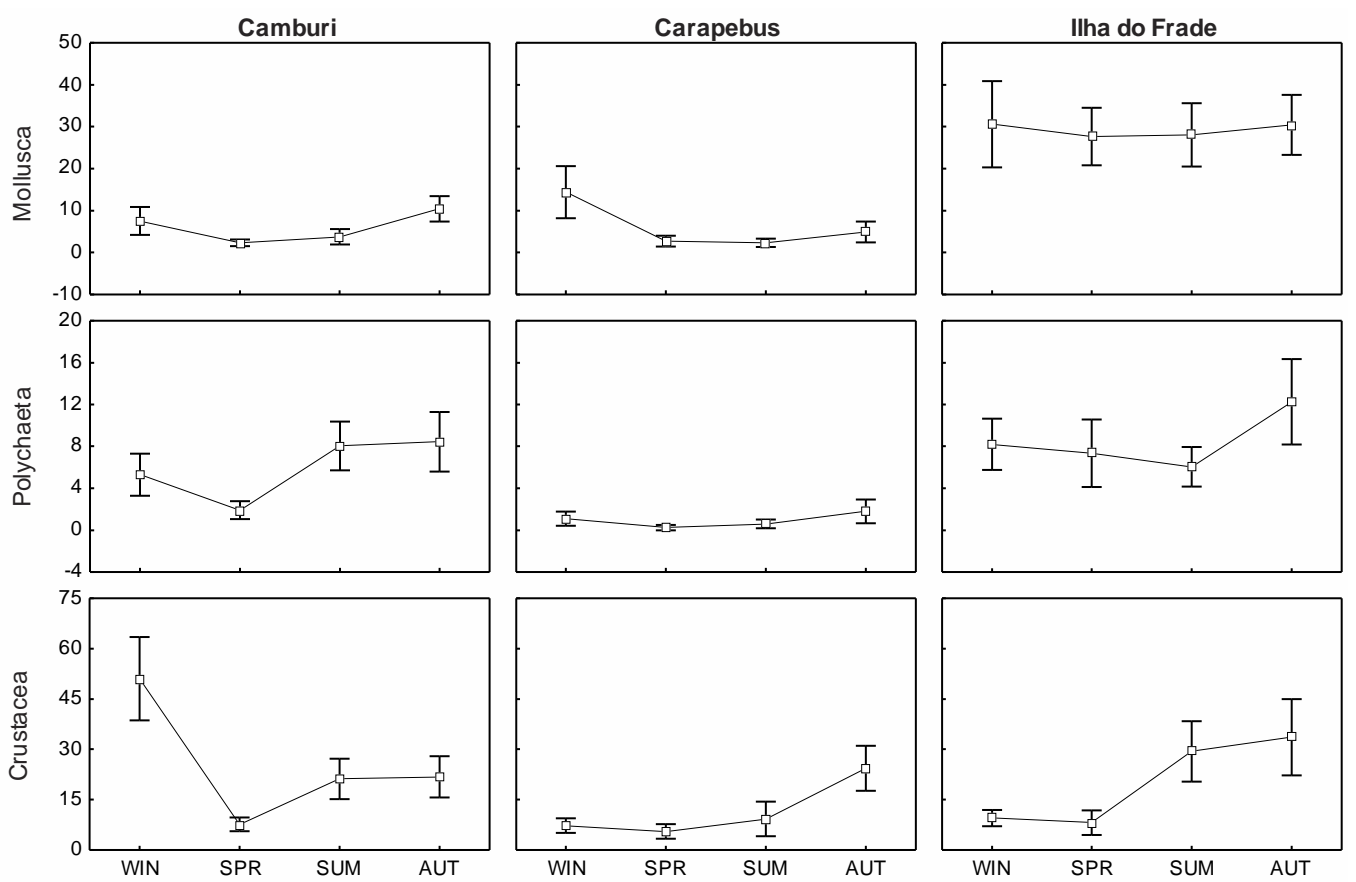

Fig. 4. Mean $\pm 95 \%$ confidence interval of abundance of main groups sampled at each sampling site by season. WIN, Winter; SPR, Spring; SUM, Summer; AUT, Autumn.

Table 2. Results of two-way ANOVA and supplementary Tukey HSD test applied to the sampling sites, seasons, and their interaction. The asterisk $(*)$ indicates significant result $(p<0.01)$. IFR, Ilha do Frade; CAM, Camburi; CAR, Carapebus; WIN, Winter; SPR, Spring; SUM, Summer; AUT, Autumn.

\begin{tabular}{|c|c|c|c|}
\hline \multicolumn{4}{|c|}{ Two-Way Anova } \\
\hline Abundance & $\boldsymbol{F}$ & d.f. & Tukey HSD \\
\hline Sampling sites & $* 128.8$ & 2 & $(\mathrm{IFR}) \neq(\mathrm{CAM}) \neq(\mathrm{CAR})$ \\
\hline Season & $* 44.5$ & 3 & $(\mathrm{WIN}=\mathrm{AUT}) \neq(\mathrm{SPR}) \neq(\mathrm{SUM})$ \\
\hline Sampling sites $\times$ Season & $* 11.0$ & 6 & - \\
\hline \multicolumn{4}{|l|}{ Richness } \\
\hline Sampling sites & $* 245.8$ & 2 & $(\mathrm{IFR}) \neq(\mathrm{CAM}) \neq(\mathrm{CAR})$ \\
\hline Season & $* 59.7$ & 3 & $(\mathrm{WIN}=\mathrm{AUT}) \neq(\mathrm{SPR}) \neq(\mathrm{SUM})$ \\
\hline Sampling sites $\times$ Season & $* 8.0$ & 6 & - \\
\hline \multicolumn{4}{|l|}{ Diversity } \\
\hline Sampling sites & $* 102.0$ & 2 & $(\mathrm{IFR}=\mathrm{CAM}) \neq(\mathrm{CAR})$ \\
\hline Season & $* 23.3$ & 3 & $(\mathrm{WIN}=\mathrm{AUT}) \neq(\mathrm{SPR}=\mathrm{SUM})$ \\
\hline Sampling sites $\times$ Season & 2.5 & 6 & - \\
\hline \multicolumn{4}{|l|}{ Evenness } \\
\hline Sampling sites & $* 12.3$ & 2 & $(\mathrm{IFR}=\mathrm{CAR}) \neq(\mathrm{CAM})$ \\
\hline Season & 0,8 & 3 & - \\
\hline Sampling sites $\times$ Season & 2,8 & 6 & - \\
\hline
\end{tabular}



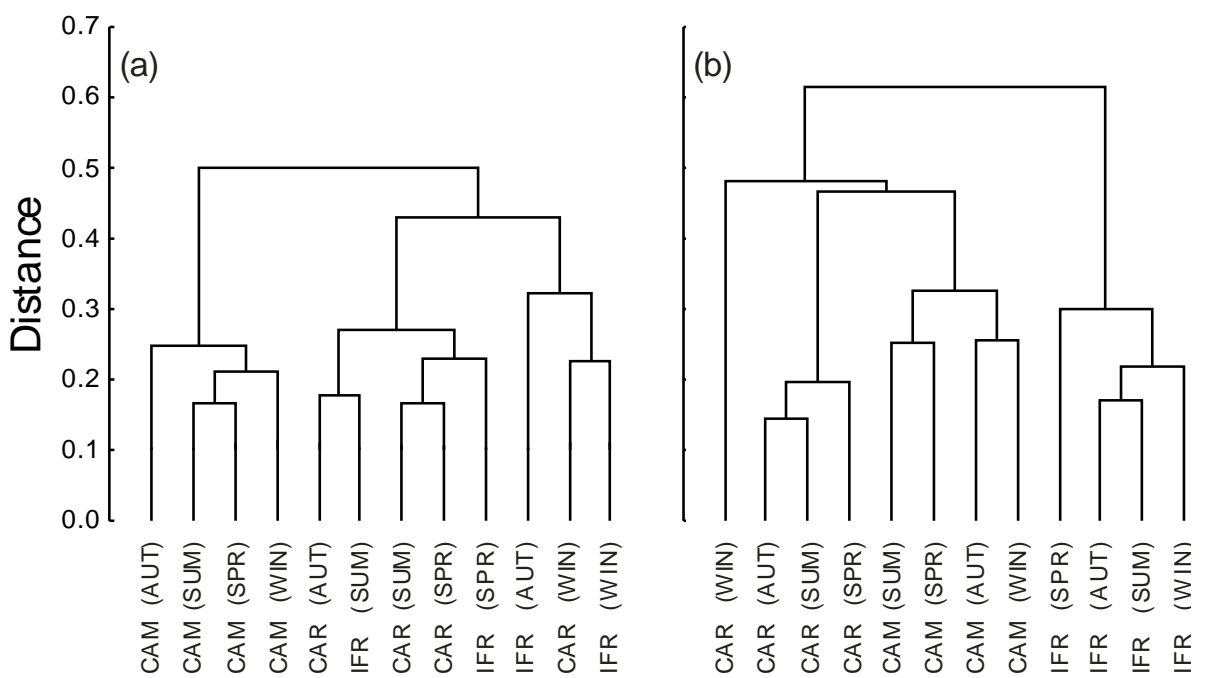

Fig. 5. Dendograms of dissimilarity of (a) physicochemical and biological, and (b) community parameters; both grouped by sampling site and by season.

\section{Discussion}

The physicochemical properties of water strongly influence coastal communities in different marine systems (JACOBUCCI et al., 2006). In this study, the sites sampled showed no great differences in water temperature and dissolved oxygen. However, as was to be expected, the salinity was higher in the open sea off Carapebus than at the two other sites located within the bay. Conversely, the amount of organic matter contained in the water was higher inside the bay due to the influence of domestic sewage. The highest organic matter level present in the sediment retained below the algal mat of Camburi may be explained by its fine granulometry (silt-clay). The algal biovolume was directly related to the hydrodynamic level. According to NEGREIROSFRANSOZO et al. (1991), the large variation in the physicochemical parameters of the water is usually found in sites adjacent to rivers, which can influence the abundance and richness of the phytal organisms.

A pronounced variation in the abiotic variables was recorded between the seasons of the year and this might be associated with the rainfall regime and the highly oscillating water temperature.

The high diversity (four genus, six species) of articulated calcareous algae recorded in the present study (a total of five genus are known for the Brazilian coast, according to ARANTES et al., 1995) has contributed to the development of a heterogeneous habitat in the intertidal region (FIGUEIREDO et al., 2004), confirming the importance of these algae in sheltering numerous vagile fauna in intertidal areas.
The differences in the composition of calcareous algae between sampling sites are probably caused by the high amount of organic matter (both in the water and in the sediment) at Ilha do Frade and Camburi, favoring Amphiroa, the second most abundant alga at these sites. This observation corroborates the results of TAOUIL and YONESHIGUE-VALENTIN (2002). High concentrations of organic matter can affect the physiology of calcareous algae, causing changes in the length and arrangement of the thallii (HORTA et al., 2008). Tangles cause the retention of sediment among thallii, creating suitable microhabitats for the fauna (MASUNARI, 1982; 1983).

The ability of the alga Amphiroa to accumulate sediment is related to its finely branched thallii and the short distances that separate them (MASUNARI, 1982; 1983). Consequently, the multiple substrate surfaces favor the deposition of sediment and organic matter which, in turn, serves as a food source capable of supporting an abundant and diverse epifauna (MASUNARI, 1982; 1983; PAULA; ESTON, 1989). Besides, differences in the concentrations of organic matter in water, sediment and consequently among calcareous algae thallii, associated with suitable physicochemical conditions, can promote the enrichment of the nutrients in the water column, increasing both the proliferation of epiphytes and the number of their consumers (SCHAFFELKE, 1999; TANAKA; LEITE, 2003). According to Kjerfve et al. (1997), domestic and industrial sewage are the main source of organic matter in the coast zones. The higher content of 
organic matter in water and sediment due to domestic and industrial sewage observed on the Ilha do Frade and at Camburi contributed, therefore, to the higher abundance, total richness and diversity found at these sites. This evidence is supported by the high abundance of Mollusca C. rhizophorae, F. rosea and B. aculeatus, Polychaeta Nothria sp. and Langerhans sp., Crustacea Caprella sp., Aruga holmesi, Isopoda and Tanaidacea, and Echinodermata Amphipholis squamata - these taxa being closely related to rich organic matter in sediment, as they are detritivores or filter-feeders (MASUNARI, 1982). Similar results have already been found with Polychaeta (see GALLMETZER et al., 2005; GIANGRANDE et al., 2005) and Crustacea (see KELAHER; CASTILHA, 2005). The growth of epiphytes on calcareous algae also seems to have favored the settlement of organisms with different feeding habits, such as the Crustacea $H$. media, H. nigra and E. brasiliensis. Studies in the State of São Paulo, Brazil, have concluded that, despite the potential harm of epiphytes to substrate algae, they lead to an increase in the abundance of Amphipoda and in the species richness of other invertebrates in that region (see JACOBUCCI et al., 2006; LEITE et al., 2007).

The Ilha do Frade presented the lowest hydrodynamic, Camburi an intermediary hydrodynamic and Carapebus the highest hydrodynamic levels. The highest algal biovolume found at Carapebus may be associated with high hydrodynamism and a low concentration of organic matter both in water and sediment. An area of high hydrodynamism leads to a greater mixing in the water column, creating a more physicochemically homogeneous liquid, and favoring the development of more complex interlaced thallii in articulated calcareous algae (STENECK; DETHIER, 1994; FIGUEIREDO et al., 2004).

Besides the organic matter content, the hydrodynamic level of the sampling sites contributes to the development of communities with different parameters. Algae in habitats with more intense hydrodynamism retain less sediment between the thallii, which can reduce abundance and species richness (MASUNARI, 1982) as a result of the consequent interference in the settlement of the organisms, in coastal environments (DUBIASKISILVA; MASUNARI, 1995). Several research projects have been undertaken to study the relationship between hydrodynamism and the phytal community and have demonstrated that this is an essential factor in the structuring of communities on macroalgae (e.g., JACOBI, 1987; OIGMAN-PSZCZOL et al., 2004; PAGLIOSA, 2006). The results of this study indicate that organic matter content and hydrodynamism are essential for species abundance and richness, thus corroborating the conclusions of previous studies.
The temporal variations in the physicochemical variables of the water, associated with rainfall, can also lead to variations in algal biovolume, abundance, richness and diversity (BRITO et al., 2005; CHOLLETT; BONE, 2007). The sudden increase in rainfall, as occurred in the spring, caused an increase in freshwater input at the sampling sites, decreasing the salinity and concentration of organic matter in the water. The effects of this can be observed in algal biovolume and fauna, especially of the Crustacea, which is the group most sensitive to sudden changes in physicochemical variables, as has been concluded by studies on rocky shores in the Mediterranean Sea (see BRITO et al., 2005), Africa, England, New Zealand (see MENGE, 2000), and Venezuela (see CHOLLETT; BONE, 2007).

The dominance of Crustacea and Mollusca on articulated calcareous algae has also been observed by Masunari (1982, 1983). The species richness found in this present study was slightly higher than that found by Masunari (1982), and by Kelaher and Castilha (2005) who studied the fauna of calcareous algae, but it was much higher than that found by Jacobucci et al. (2006) on Sargassum spp. These studies have shown the highly suitable shelter enhanced by Rhodophyta for invertebrate fauna as compared to that provided by other groups of algae.

The presence of the exotic mollusc Isognomon bicolor (Adams, 1845) on the Ilha do Frade and at Camburi deserves special attention. Its introduction into Brazilian waters has been attributed to ballast water (FERREIRA et al., 2009) and, unfortunately, the species has been expanding its geographical distribution in Brazil since the mid1990 s, invading spaces originally colonized by commercially exploited species such as $C$. rhizophorae and Perna perna (Linnaeus, 1758) (JACOBUCCI et al., 2006).

The phytals studied at the three sampling sites of this study can be characterized as follows: (1) Ilha do Frade, a site protected from the direct action of waves, with a large amount of organic matter in the water, Corallinaceae with more entangled thallii forming a low carpet, the associated fauna being of the highest abundance, species richness and diversity; (2) Camburi, a moderately protected site with intermediate hydrodynamism, a large amount of organic matter in the sediment, Corallinaceae with entangled thallii forming a low carpet, the associated fauna presenting median values of abundance, species richness and diversity and (3) Carapebus, the most exposed site with intense hydrodynamism, low quantities of organic matter in both water and sediment, Corallinaceae forming a tall carpet of voluminous erect thallii, the associated fauna having the lowest values of abundance, species richness, diversity and evenness. 
These results bring out the great species richness and diversity present in the phytal banks of the Espírito Santo coast, reinforcing the need for the appropriate management and conservation of this highly complex ecosystem that plays such an important role in the food chain. Future studies focusing on the main factors that cause changes in the structure of intertidal communities and in the species that act as bioindicators of environmental stress will contribute to the better understanding of coastal ecosystems.

\section{ACKNOWLEDGMENTS}

We wish to thank Agnaldo Silva Martins, Jean-Christophe Joyeux, Renato Paes Moure and Rosebel Cunha Nalesso of the Postgraduate Course for Animal Biology of the Federal University of Espírito Santo (UFES) for their helpful discussions; Cristina Aparecida Gomes Nassar for her review of this manuscript; Amanda Ferreira e Cunha and collaborators for providing the methodology for the measurement of hydrodynamism; the Laboratories of Malacology (UFES) and Carcinology (National Museum of Rio de Janeiro) for the identification of the species; Cepemar Meio Ambiente for their logistic support; Danielle de Oliveira Moreira and Lianne Joy Mokfienski for their help with the translation of this manuscript into English, and the anonymous referees for their valuable comments.

\section{REFERENCES}

ARANTES, P. V. S.; NASSAR, C. A. G.; GESTINARI, L. M. S. Comunidades de algas calcárias articuladas na baía do Espírito Santo. Nerítica, v. 9, n. 1-2, p. 33-48, 1995.

BARRETO, C. C. Heterogeneidade espacial do habitat e diversidade específica: implicações ecológicas e métodos de mensuração. Oecol. Bras., v. 7, n. 1, p. 121-153, 1999.

BRITO, M. C.; MARTIN, D.; NUNEZ, J. Polychaetes associated to a Cymodocea nodosa meadow in the Canary Islands: assemblage structure, temporal variability and vertical distribution compared to other Mediterranean seagrass meadows. Mar. Biol., v. 146, n. 3, p. 467-481, 2005.

CHOLLETT, I.; BONE, D. Effects of heavy rainfall on polychaetes: differential spatial patterns generated by a large-scale disturbance. J. Exp. Mar. Biol. Ecol., v. 340, n. 2, p. 113-125, 2007.

DUBIASKI-SILVA, J.; MASUNARI, S. Ecologia populacional dos Amphipoda (Crustacea) dos fitais de Caiobá, Matinhos, Paraná, Brasil. Rev. Bras. Zool., v. 12, n. 2, p. 373-396, 1995.

FERREIRA, B. P.; MAIDA, M. Fishing and the future of Brazil's northeastern reefs. InterCoast, v. 38, n. 1, p. 22 23, 2001.
FERREIRA, C. E. L.; JUNQUEIRA, A. O. R.; VILLAC, M. C.; LOPES, R. M. Marine Bioinvasions in the Brazilian Coast: brief Report on History of Events, Vectors, Ecology, Impacts and Management of Non-indigenous Species. In: RILOV, G.; CROOKS, J. A. (eds.). Biological Invasions in Marine Ecosystems. Berlin: Springer-Verlag, 2009, p. 459-477.

FIGUEIREDO, M. A. O.; BARRETO, M. B. B.; REIS, R. P. Caracterização das macroalgas nas comunidades marinhas da Área de Proteção Ambiental de Cairuçú, Parati, RJ: Subsídios para futuros monitoramentos. Rev. Bras. Bot., v. 27, n. 1, p. 11-17, 2004.

GALLMETZER, I.; PFLUGFELDER, B.; ZEKELY, J.; OTT, J. A. Macrofauna diversity in Posidonia oceanica detritus distribution and diversity of mobile macrofauna in shallow sublittoral accumulations of Posidonia oceanica detritus. Mar. Biol., v. 147, n. 2, p. 517-523, 2005.

GIANGRANDE, A.; LICCIANO, M.; MUSCO, L. Polychaetes as environmental indicators revisited. Mar. Pollut. Bull., v. 50, n. 11, p. 1153-1162, 2005.

GUERRA-GARCÍA, J. M.; GARCÍA-GÓMEZ, J. C. The Spatial Distribution of Caprellidea (Crustacea: Amphipoda): A Stress Bioindicator in Ceuta (North Africa, Gibraltar Area). Mar. Ecol., v. 22, n. 4, p. 357367, 2001.

HORTA, P. A.; SALLES, J. P.; BOUZON, J. L.; SCHERNER, F.; CABRAL, D. Q.; BOUZON, Z. L. Composição e estrutura do fitobentos do infralitoral da Reserva Biológica Marinha do Arvoredo, Santa Cataria, Brasil: implicações para conservação. Oecol. Bras., v. 12, n. 2, p. 243-257, 2008.

HULL, S. L. Intertidal ostracod (Crustacea: Ostracoda) abundance and assemblage. structure within and between four shores in north-east England. J. Mar. Biol. Assoc. U.K., v. 79, n. 6, p. 1045-1052, 1999.

JACOBI, C. M. Spatial and temporal distribution of Amphipoda associated with mussel beds from the Bay of Santos (Brazil). Mar. Ecol. Prog. Ser., v. 35, n. 1-2, p. 51-58, 1987.

JACOBUCCI, G. B.; GÜTH, A. Z.; TURRA, A.; MAGALHÃES, C. A.; DENADAI, M. R.; CHAVES, A. M. R.; SOUZA, E. C. F. Levantamento da macrofauna associada a Sargassum spp. na ilha da Queimada Pequena, Estação Ecológica dos Tupiniquins, litoral sul do Estado de São Paulo, Brasil. Biota Neotrop., v. 6, n. 2, p. 1-8, 2006.

KELAHER, B. P.; CASTILHA, J. C. Habitat characteristics influence macrofaunal communities in coralline turf more than mesoscale coastal upwelling on the coast of Northern Chile. Estuar. Coast. Shelf Sci., v. 63, n. 1-2, p. 155-165, 2005.

KJERFVE, B.; RIBEIRO, C. H. A.; DIAS, G. T. M.; FILIPPO, A. M.; QUARESMA, V. D. Oceanographic characteristics of an impacted coastal bay: Baia de Guanabara, Rio de Janeiro, Brazil. Cont. Shelf Res., v. 17, n. 13, p. 1609-1617, 1997.

KREBS, C. J. Ecological methodology. 2nd edition. San Francisco: Benjaming Cummings, 1989.617 p.

LEITE, F. P. P.; TANAKA, M. O.; GEBARA, R. S. Structural variation in the brown alga Sargassum cymosum and its effects on associated amphipod assemblages. Braz. J. Biol., v. 67, n. 2, p. 215-221, 2007. 
MASUNARI, S. Organismos do fital Amphiroa beauvoisii Lamouroux, 1816 (Rhodophyta: Corallinaceae) I. Autoecologia. Bol. Zool. Univ. São Paulo, v. 7, n. 1, p. $57-148,1982$.

MASUNARI, S. The phytal of the Alga Amphiroa fragilissima (Linnaeus) Lamouroux, 1816. Stud. Neotr. Fauna Environ., v. 18, n. 3, p. 151-161, 1983.

MENGE, B. A. Top-down and bottom-up community regulation in marine rocky intertidal habitats. J. Exp. Mar. Biol. Ecol., v. 250, n. 1-2, p. 257-289, 2000.

NASSAR, C. A. G.; VALENTIN, Y. Y. Iron ore particles on four seaweed species from Camburi beach (Espírito Santo state, Brazil). Braz. J. Oceanogr., v. 54, n. 2-3, p. 155-159, 2006.

NEGREIROS-FRANSOZO, M. L. N.; FRANSOZO, A.; PINHEIRO, M. A. A.; MANTELATTO, F. L. M.; SANTOS, S. Caracterização física e química da Enseada de Fortaleza, Ubatuba, SP. Rev. Bras. Geoc., v. 21, n. 2, p. 114-120, 1991.

OIGMAN-PSZCZOL, S. S.; FIGUEIREDO, M. A. O.; CREED, J. C. Distribution of benthic communities on the tropical rocky subtidal of Armação dos Búzios, southeastern Brazil. Mar. Ecol., v. 25, n. 3, p. 173-190, 2004

PAGLIOSA, P. R. Distribuição da macrofauna bêntica do entremarés ao sublitoral em uma praia estuarina da Baía da Babitonga, Sul do Brasil. Biotemas, v. 19, n. 1, p. 2533, 2006.

PAULA, E. J.; ESTON, V. R. Secondary succession on an exposed rocky intertidal algal community of the State of São Paulo, Brazil. Brazil. Bol. Bot. Univ. São Paulo, v. 11, n. 1, p. 1-9, 1989.

POCKLINGTON, P.; WELLS, P. G. Polychaetes: key taxa for marine environmental quality monitoring. Mar. Pollut. Bull., v. 24, n. 12, p. 593-598, 1992.

SABINO, C. M.; VILLAÇA, R. Estudo comparativo de métodos de amostragem de comunidades de costão. Rev. Bras. Biol., v. 59, n. 3, p. 407-419, 1999.

SCHAFFELKE, B. Particulate organic matter as an alternative nutrient source for tropical Sargassum species (Fucales, Phaeophyceae). J. Phycol., v. 35, n. 6, p. 1150-1157, 1999

STENECK, R. S.; DETHIER, M. N. A functional group approach to the structure of algal-dominated communities. Oikos, v. 69, n. 3, p. 476-498, 1994.

STERZA, J. M.; FERNANDES, L. L. Zooplankton community of the Vitória bay estuarine system (southeastern Brazil). Characterization during a threeyear study. Braz. J. Oceanogr., v. 54, n. 2-3, p. 95-105, 2006.
SUGUIO, K.; MARTIN, L.; BITTENCOURT, A. C. S. P. DOMINGUEZ, J. M. L.; FLEXOR, J. M.; AZEVEDO, A. E. G. Flutuações do nível relativo do mar durante o Quaternário Superior ao longo do litoral brasileiro e suas implicações na sedimentação costeira. Rev. Bras. Geo., v. 15 , n. 4 , p. $273-286,1985$.

SZÉCHY, M. T. M.; PAULA, E. J. Padrões estruturais quantitativos de bancos de Sargassum (Phaeophyta, Fucales) do litoral dos estados do Rio de Janeiro e São Paulo, Brasil. Rev. Bras. Bot., v. 23, n. 2, p. 121-132, 2000.

TÂMEGA, F. T. S.; FIGUEIREDO, M. A. O. Distribuição das algas calcárias incrustantes (Corallinales, Rhodophyta) em diferentes habitats na Praia do Forno, Armação dos Búzios, Rio de Janeiro. Rodriguésia, v. 56, n. 87, p. 123-132, 2005.

TANAKA, M. O.; LEITE, F. P. P. Spatial scaling in the distribution of macrofauna associated with Sargassum stenophyllum (Mertens) Martius: analyses of faunal groups, gammarid life habits, and assemblage structure. J. Exp. Mar. Biol. Ecol., v. 293, n. 1, p. 1-22, 2003.

TAOUIL, A.; YONESHIGUE-VALENTIN, Y. Alterações na composição florística das algas da Praia de Boa Viagem (Niterói, RJ). Rev. Bras. Bot., v. 25, n. 4, p. 405-412, 2002.

TEIXEIRA, V. L.; PEREIRA, R. C.; MARQUES JR, A. N.; LEITÃO, C. M.; SILVA, C. A. R. Seasonal variations in infralittoral seaweed communities under a pollution gradient in Baía de Guanabara, Rio de Janeiro (Brazil). Cienc. Cult., v. 39, n. 4, p. 423-428, 1987.

UNDERWOOD, A. J.; PETERSON, C. H. Towards an ecological framework investigating pollution. Mar. Ecol. Prog. Ser., v. 46, n. 1, p. 227-234, 1988.

WETZEL, R. G.; LIKENS, G. E. Limnological analysis. 2nd edition. New York: Springer-Verlag, 1991. 429 p.

WYNNE, M. J. A check-list of benthic marine algae of the tropical and subtropical western Atlantic: second revision. Nova Hedw. Beih., v. 129, n. 1, p. 1-152, 2005.

ZAR, J. H. Biostatistical Analysis. 4th edition. Upper Saddle River: Prentice Hall, 1999. 931 p.

(Manuscript received 27 August 2009; revised 23 June 2010; accepted 13 July 2010) 